\title{
First Case of Severe Pneumonia due to SARS-CoV2 (COVID-19) in Mexico City
}

\author{
Solis Ayala $\mathrm{E}^{1}$, Aguilar Medina $\mathrm{S}^{2}$, Cano Fano $\mathrm{BE}^{3}$, De Luna $\mathrm{G}^{4}$, Frias $\mathrm{M}^{5}$ and Castañeda Mendez \\ $\mathrm{PF}^{6 *}$ \\ ${ }^{1}$ Department of Internal Medicine/Infectious Diseases, Hospial San Angel Inn Universidad, Mexico \\ ${ }^{2}$ Head Chief of Pneumology Department, Hospital San Angel Inn Universidad, Mexico \\ ${ }^{3}$ Head Chief of Hospitalization, Hospital San Angel Inn Universidad, Mexico \\ ${ }^{4}$ Department of Pneumology, Hospital San Angel Inn Universidad, Mexico \\ ${ }^{5}$ Intesive Care Unit, Hospital San Angel Inn Universidad, Mexico \\ ${ }^{6}$ Department of Infectious Diseases, Medica Sur/ Hospital san Angel Inn Universidad, Mexico \\ *Corresponding author: Castañeda Mendez PF, Department of Infectious Diseases, Medica Sur/ Hospital san Angel Inn Universi- \\ dad, Mexico
}

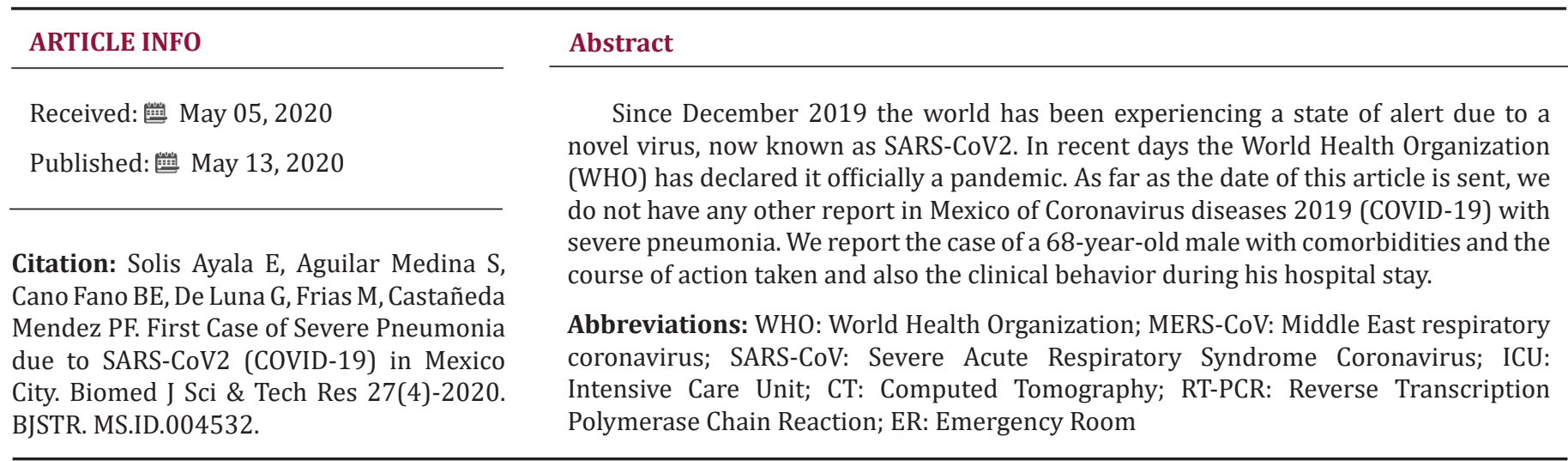

\section{Introduction}

Since December 2019 the world has been experiencing a state of alert due to a novel virus, now known as SARS-CoV-2. In recent days the WHO has declared it officially a pandemic. The coronaviruses are classified within Nidovirales order, the viruses that affect humans are: alpha coronaviruses (HCoV-229E and HCoV-NL63) and beta coronaviruses (HCoV-HKU1, HCoV-OC43, Middle East respiratory coronavirus (MERS-CoV) and severe acute respiratory syndrome coronavirus (SARS-CoV) [1]. The new coronavirus reported is the seventh strain to cause respiratory disease in humans, this virus falls into the genus beta coronaviruses [2]. According to Guan $\mathrm{Z}$ et al. in the recent article of clinical characteristics of coronavirus disease [3]. They had studied a total of 1099 patients with confirmed COVID-19. They measured three endpoints: admission to intensive care unit, the use of mechanical ventilation, or death. They reported that from the 1099 patients the median age was 47 years, the proposed endpoint occurred in 67 patients (6.1\%), 5.0\% were admitted to the Intensive Care Unit (ICU), $2.3 \%$ required invasive mechanical ventilation and $1.4 \%$ died.

The frequency of symptoms were reported as follow: fever $43.8 \%$ on admission and $88.7 \%$ during hospitalization, cough $67.8 \%$. It is reported a median incubation period of 4 days in this study, but this information is slightly different than the one reported by Li Q [4] in which the median of symptoms is 5.2 days with the $95^{\text {th }}$ percentile of the distribution at 12.5 days. Regarding radiologic findings the most common image in computed tomography (CT) scan is ground-glass opacities in up to $56.4 \%$ on admission, it is important to mention that in patients with severe disease a total of $2.9 \%$ of the patients didn't have any radiological findings in the CT scan [3]. In the laboratory tests in another series of cases 
published by Chen $\mathrm{N}$ et al. it is mentioned that out of 140 patients, 61 patients (44\%) had lymphopenia, 58 (41\%) had elevation of hepatic transaminases, procalcitonin levels were normal in almost all patients except those with secondary infection [5].

The diagnosis in Mexico is made according to international standards similar to the ones reported by Ying-Hui J et al. At this moment the first approach is to assess if the patient is within the standard definition of suspicious case; which recalls for anyone who has been in contact with a confirmed COVID-19 infected patient or someone who has traveled to any of the high incidence countries. Then ask about the symptoms being of high suspicion the ones who report fever, dry cough or shortness of breath. The first step is to take a rapid flu test, if this one is negative we proceed to order reverse transcription polymerase chain reaction (RT-PCR) of respiratory pathogens, if this second test proves to be negative, we request the sanitary jurisdiction to take a respiratory swab for COVID-19 testing. The test is done also by RT PCR for COVID-19 with an estimated time for response of approximately 12 to 24 hours.

\section{Case report}

We present the case of a 68-year-old male that was admitted at the emergency room (ER) of the San Angel Inn Universidad Hospital in Mexico City, last March $11^{\text {th }}, 2020$; due to presenting disorientation and delusion ideas.

The patient presents the following relevant background:

a) Intense tobacco use suspended 30 years ago.

b) Intense alcohol use suspended 5 years ago.

c) Chronic ischemic cardiopathy, 7 years ago, the patient presented acute coronary syndrome requiring the placement of a stent currently with double platelet antiaggregation.

d) Diabetes mellitus type 2 currently treated with metformin.

e) Systemic arterial hypertension, treated with olemsartan/ hydrochlorothiazide

f) Previous to his admission, the patient visited the following tourist destinations:

i) February $24^{\text {th }}, 2020-7$ day stayed in Madrid.

ii) March 1 $1^{\text {st }}, 2020$ - 2 day stayed in Mexico.

iii) March $3^{\text {rd }}, 2020$ - 7 day stayed in Cuba.

Condition started 5 days prior to his admission by presenting asthenia andadynamia accompanied by hyporexia; and subsequently presenting fever $38.3^{\circ} \mathrm{C}\left(100.9^{\circ} \mathrm{F}\right)$ and incoherent speech. Due to the persistence of the symptomatology, his companion decided to bring him to the ER. During the led interrogatory, patient reported presenting the last days before his admission, dry cough, and mild dyspnea. During the initial physical examination, the patient's vital sings with blood pressure $120 / 77 \mathrm{mmHg}$, heartbeat rate 124 beats per minute respiratory rate 32 breaths per minute temperature $37.8^{\circ} \mathrm{C}\left(100.0^{\circ} \mathrm{F}\right)$ peripheral oxygen saturation $79 \%$ without supplementary oxygen, no alteration in consciousness state, lung examination with disseminated crackles. During initial approach, patient is identified with radiographic data from an unenhanced chest computed tomography with multiple consolidative peripheral opacities with ground-glass density in multiple lobes (Figures 1-6) with a peripheral distribution, which has been reported as a common finding of SARS-CoV-2 pneumonia [6].
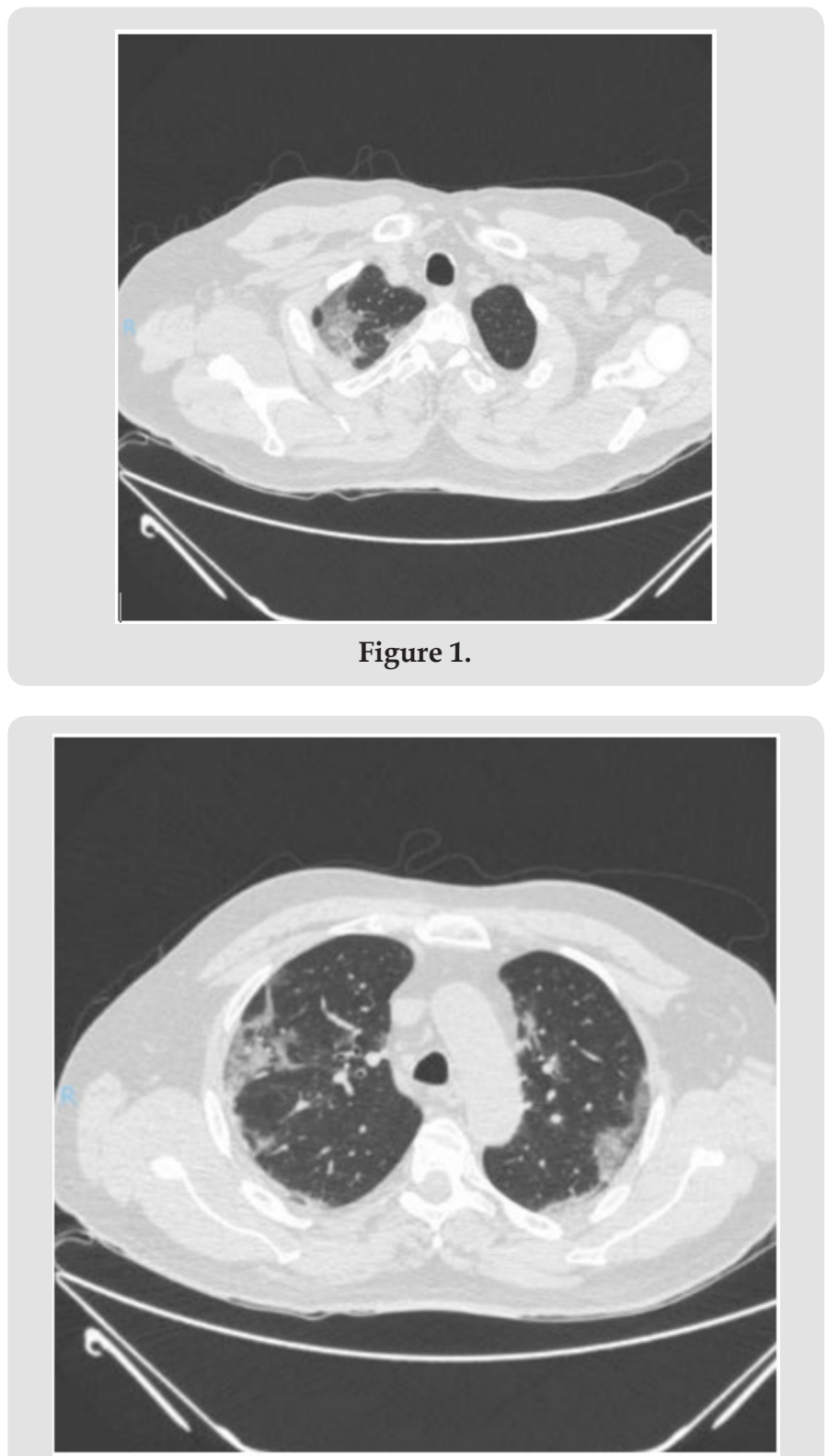

Figure 2. 


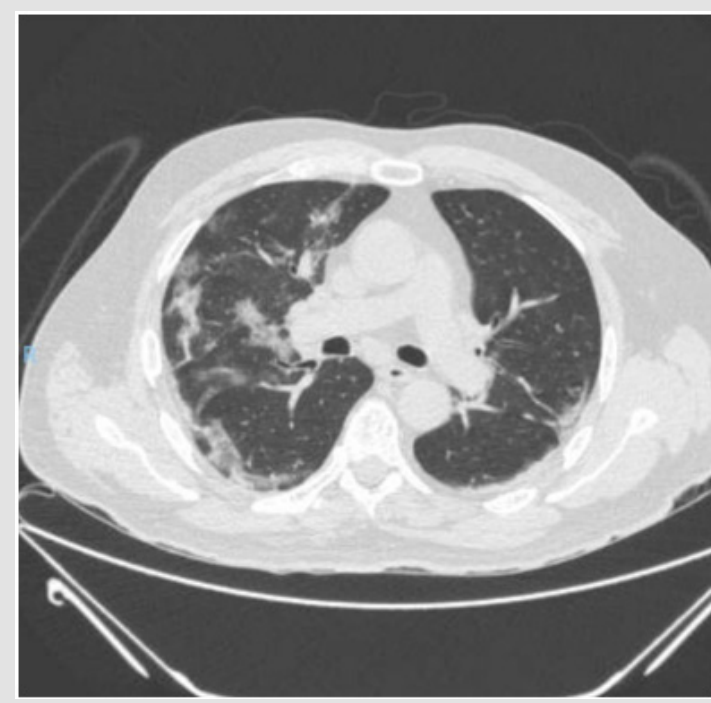

Figure 3.

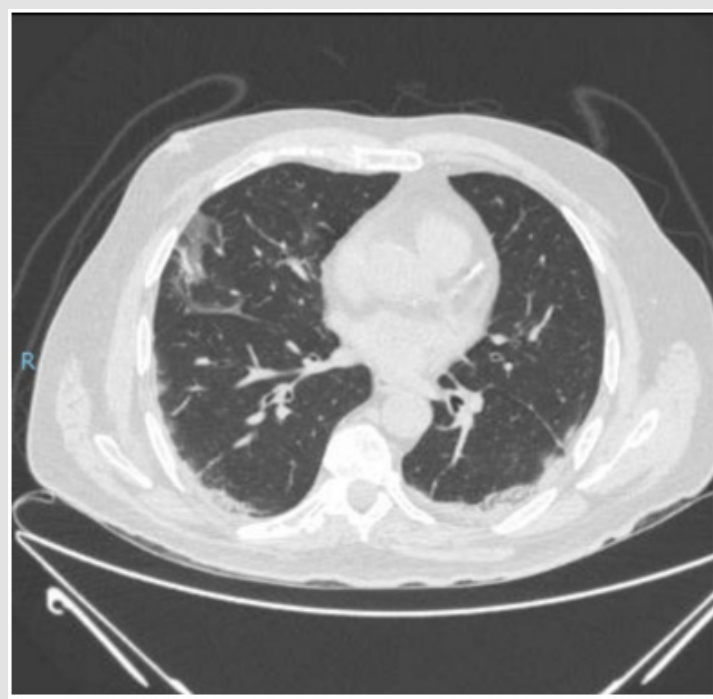

Figure 4.

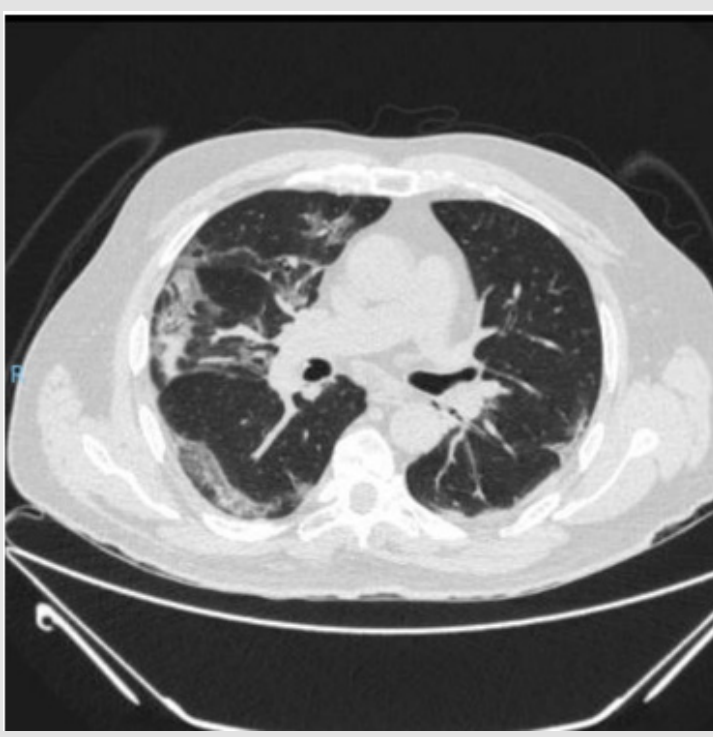

Figure 5.

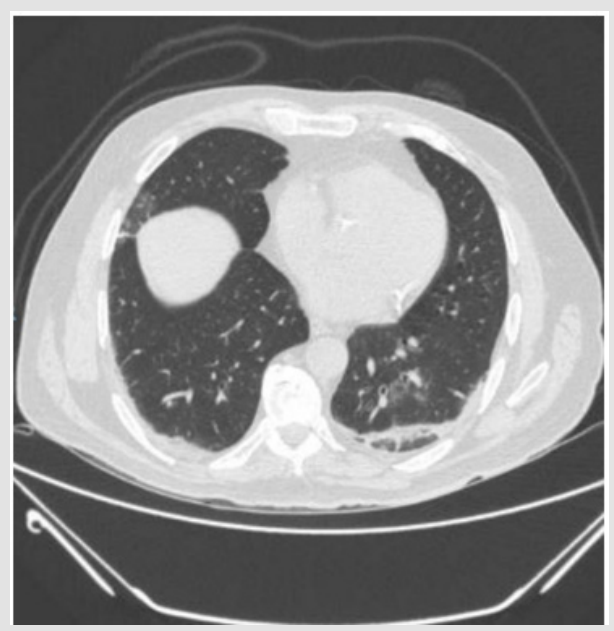

Figure 6.

Table 1: Laboratories at admission

\begin{tabular}{|c|c|}
\hline \multicolumn{2}{|c|}{ Completed Blood Cell Count } \\
\hline Hemoglobin (g/dL) & 12.13 \\
\hline Hematocrit (\%) & 36.4 \\
\hline Platelet $(\times 103 / \mu \mathrm{L})$ & 287 \\
\hline Leukocytes $\left(\times 10^{\wedge} 3 / \mu \mathrm{L}\right)$ & 9.27 \\
\hline Neutrophiles $\left(\times 10^{\wedge} 3 / \mu \mathrm{L}\right)$ & 8.15 \\
\hline Lymphocytes $\left(\times 10^{\wedge} 3 / \mu \mathrm{L}\right)$ & 0.464 \\
\hline \multicolumn{2}{|c|}{ Blood Gases } \\
\hline $\mathrm{pH}$ & 7.51 \\
\hline $\mathrm{pCO}_{2}(\mathrm{mmHg})$ & 25.9 \\
\hline $\mathrm{pO}_{2}(\mathrm{mmHg})$ & 52.2 \\
\hline $\mathrm{HCO}_{3}(\mathrm{mmol} / \mathrm{L})$ & 20.7 \\
\hline $\mathrm{SO}_{2}(\%)$ & 88.1 \\
\hline p50 (mmHg) & 25.2 \\
\hline Lactate (mmol/L) & 2.3 \\
\hline \multicolumn{2}{|c|}{ Blood Chemistry } \\
\hline Sodium $(\mathrm{mmol} / \mathrm{L})$ & 135 \\
\hline Potasium (mmol/L) & 3.8 \\
\hline Chlorine (mmol/L) & 96 \\
\hline Calcium (mmol/L) & 8.6 \\
\hline Magnesium (mmol/L) & 1.7 \\
\hline Glucose (mg/dL) & 276 \\
\hline Creatinine mg/dL) & 0.7 \\
\hline $\operatorname{Albumin}(\mathrm{g} / \mathrm{dL})$ & 3.2 \\
\hline Lactic dehydrogenase $(\mathrm{U} / \mathrm{L})$ & 311 \\
\hline Alanine transaminase $(\mathrm{U} / \mathrm{L})$ & 190 \\
\hline Aspartate transaminase (U/L) & 160 \\
\hline Gamma glutamyl transpeptidase (U/L) & 297 \\
\hline \multicolumn{2}{|c|}{ Inflammatory Markers } \\
\hline $\mathrm{C}$ reactive protein $(\mathrm{mg} / \mathrm{dL})$ & 31.3 \\
\hline D dimer $(\mathrm{ng} / \mathrm{mL})$ & 1103 \\
\hline Ferritin (ng/mL) & 5329.28 \\
\hline Procalcitonine (ng/dL) & 0.53 \\
\hline
\end{tabular}


Once identified the risk factors and suspicious for a COVID-19 case the patient was isolated according to hospital policies. RTPCR samples were taken for respiratory virus and then notified to the epidemiology department. Empirical treatment was initiated in cooperation with infectious diseases department for atypical pneumonia and possible COVID-19 with supplementary oxygen, bronchodilators (ipratropium, fluticasone and olodaterol/ tiotropium), ceftaroline, clarithromycin and oseltamivir. The day after, the INDRE (Instituto de Diagnóstico y Referencia Epidemiólogica) notified that the patient's nasopharyngeal swap was positive for SARS-CoV-2, therefore we withdraw oseltamivir and instead hydroxychloroquine $400 \mathrm{mg}$ po bid the first day and continue $200 \mathrm{mg}$ po bid and lopinavir $400 \mathrm{mg} /$ ritonavir $100 \mathrm{mg}$ po bid were started. Laboratory findings on admission showed leukocytes of $9.27 \times 10^{3} / \mu \mathrm{L}$, neutrophilia $8.15 \times 10^{3} / \mu \mathrm{L}$, total lymphocytes of $0.464 \times 10^{3} / \mu \mathrm{L}$, Lactic dehydrogenase $311 \mathrm{U} / \mathrm{L}$, TGO 190 U/L, TGP 160 U/L (Table 1).

Table 2: Blood Gas.

\begin{tabular}{|c|c|}
\hline Date & $\mathbf{1 1 / 0 3 / 2 0}$ \\
\hline Sample & Arterial \\
\hline $\mathrm{pH}$ & 7.51 \\
\hline $\mathrm{pCO}_{2}(\mathrm{mmHg})$ & 25.9 \\
\hline $\mathrm{pO}_{2}(\mathrm{mmHg})$ & 52.2 \\
\hline $\mathrm{HCO}_{3}(\mathrm{mmol} / \mathrm{L})$ & 20.7 \\
\hline Base $(\mathrm{mmol} / \mathrm{L})$ & -0.6 \\
\hline $\mathrm{SO}_{2}(\%)$ & 88.1 \\
\hline $\mathrm{p} 50(\mathrm{mmHg})$ & 25.2 \\
\hline Lactato $(\mathrm{mmol} / \mathrm{L})$ & 2.3 \\
\hline
\end{tabular}

Arterial blood gases moderate hypoxemia $\left(\mathrm{pAO}_{2}=52.2 \mathrm{mmHg}\right)$, acute hypoventilation ( $\left.\mathrm{pACO}_{2} 25.9 \mathrm{mmHg}\right), \mathrm{pH} 7.51$, values adjusted to Mexico City height. $\mathrm{PaO}_{2} / \mathrm{FiO}_{2} 249 \mathrm{mmHg}$ (mild ARDS). At admission, the following severity scales were estimated: CURB65 (2) mortality of 9.2\%, PSI (128) Class IV; 9.3\% mortality, SMARTCOP (5) high risk of admission to the Intensive Care Unit (ICU). We would like to remind that the SMART-COP score reflects better the clinical condition of the patient. During hospitalization the respiratory treatment consisted in high flow nasal cannula witch gradually was stepped down to conventional nasal cannula 6 days after, as the patient remains stable without inflammatory systemic response or clinical data of respiratory distress we decided to discharge the patient with no need of supplementary oxygen. On a subsequent follow up he referred clinically stable without signs of active COVID-19 disease (Tables 2 \& 3).

Table 3: Blood Chemistry.

\begin{tabular}{|c|c|}
\hline Date & $\mathbf{1 1 / 0 3 / 2 0}$ \\
\hline $\mathrm{Na}(\mathrm{mmol} / \mathrm{L})$ & 135 \\
\hline $\mathrm{K}(\mathrm{mmol} / \mathrm{L})$ & 3.8 \\
\hline $\mathrm{Cl}(\mathrm{mmol} / \mathrm{L})$ & 96 \\
\hline $\mathrm{Ca}(\mathrm{mmol} / \mathrm{L})$ & 8.6 \\
\hline $\mathrm{Mg}(\mathrm{mmol} / \mathrm{L})$ & 1.7 \\
\hline $\mathrm{P}(\mathrm{mmol} / \mathrm{L})$ & 3 \\
\hline Glucosa $(\mathrm{mg} / \mathrm{dL})$ & 276 \\
\hline Urea mg/dL) & 30 \\
\hline Creatinina mg/dL) & 0.7 \\
\hline Albumina (g/dL) & 3.2 \\
\hline DHL (U/L) & 311 \\
\hline TGO (U/L) & 190 \\
\hline TGP (U/L) & 160 \\
\hline GGT (U/L) & 297 \\
\hline PCR & 31.3 \\
\hline PCT & 0.53 \\
\hline
\end{tabular}

\section{References}

1. Chan JF, Lau SK, To KK, Cheng VCC, Woo PCY, et al. (2015) Middle East respiratory syndrome coronavirus: another zoonotic betacoronavirus causing SARS-like disease. Clin Microbiol Rev 28(2): 465-522.

2. Zhu Na, Zhang D, Wang W, Li X, Yang B, et al. (2020) A novel coronavirus from patients with pneumonia in China 2019. N Engl J Med 382(8): 727 733.

3. Guan W, Ni Z, Hu Y, Liang W, Ou C, et al. (2020) Clinical Characteristics of coronavirus disease 2019 in china. N Eng J Med 382: 1708-1720.

4. Li Q, Guan X, Wu P, Wang X, Zhou L, et al. (2020) Early transmission dynamics in Wuhan, China, of novel coronavirus-infected pneumonia. $\mathrm{N}$ Engl J Med 382: 1199-1207.

5. Chen N, Zhou M, Dong X, Qu J, Gong F, et al. (2020) Epidemiological and clinical characteristics of 99 cases of 2019 novel coronavirus pneumonia in Wuhan, China: a descriptive study. Lancet 395: 507-513.

6. Ying Hui J, Lin C, Zhen Shun C, Hong C, Tong Deng, et al. (2020) A rapid advice guideline for the diagnosis and treatment of 2019 novel coronavirus (2019 $\mathrm{nCoV})$ infected pneumonia (standard version). Military Medical Research 7(1): 4.

ISSN: 2574-1241

DOI: 10.26717/BJSTR.2020.27.004532

Abdullah Faisal Aldairi. Biomed J Sci \& Tech Res

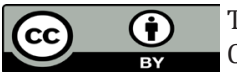

This work is licensed under Creative Commons Attribution 4.0 License

Submission Link: https://biomedres.us/submit-manuscript.php

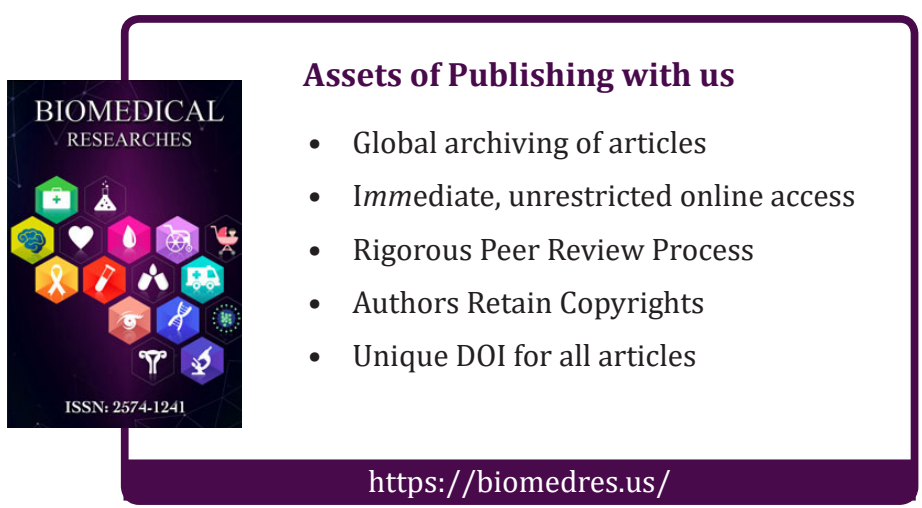

